\title{
DEMAND ANALYSIS OF INDONESIAN PULPWOOD USING TRANSCENDENTAL LOGARITHMIC MODEL: A STUDY OF THE WORLD AND SELECTED ASIAN MARKETS
}

\author{
Gunawan G.T.P. Simanjuntak ${ }^{* 1}$ and Chingyang Lin ${ }^{2}$ \\ ${ }^{1}$ Graduate Program in Economics, Faculty of Economics and Business, University of Indonesia, \\ Jl. Margonda Raya, Beji, Pondok Cina, Kota Depok, Jawa Barat 16424 \\ ${ }^{2}$ International Development Program, International University of Japan, \\ 777 Kokusai-cho Minami-uonuma Niigata Japan 949-7277
}

Received: 10 November 2016, Revised: 24 September 2017, Accepted: 17 October 2017

\begin{abstract}
DEMAND ANALYSIS OF INDONESIAN PULPWOOD USING TRANSCENDENTAL LOGARITHMIC MODEL: A STUDY IN THE WORLD AND SELECTED ASIAN MARKETS. Indonesia's pulpwood export has shown an increasing trend since 1990s. Along with Brazil, Canada, USA and Chile, Indonesia became one of the top five pulpwood exporter countries in the world. Indonesia's pulpwood was traded mainly to some Asian countries. This paper examines Indonesian pulpwood export demand during the period 1994-2014 using a Transcendental Logarithmic (TL) model with Seemingly Unrelated Regression (SUR) estimation. Export data from the five top exporter countries in four different markets (China, Korea, Japan and the world) were analysed. The important findings are as follow: firstly, logarithmic income and second order logarithmic income significantly influence the Chinese and Korean markets. Secondly, in general, Indonesia's own-prices are elastic and have negative signs (-2.308, -1.06 and -2.04 in the Korean, Japanese and the world markets, respectively). Thirdly, due to its positive sign of crossprice elasticity and also positive signs of income elasticity $(1.002,1.722$ and 0.625 in the Chinese, Korean and the world markets, respectively), Indonesian pulpwood could be categorized as a substitute and normal goods. Lastly, regarding to negative and elastic Indonesia's pulpwood own-prices, one possible policy that could be applied by the Government of Indonesia (GoI) is giving a subsidy to reduce pulpwood price by $10 \%$. Subsidy could be implemented by reducing tax and retribution such as property tax (Pajak Bumi dan Bangunan) and local retribution (Retribusi Daerab). By doing so, it would give more benefit in the Korean market compared with other markets. Indonesia's share of demand would increase from 0.28 to 0.31 with high rate of return $(>2)$. On the world markets, Indonesia's share of demand would increase from 0.08 to 0.1 with a return rate of 1.89 . This study, therefore, suggests that a subsidy policy should be implemented for pulpwood industry in Indonesia.
\end{abstract}

Keywords: Pulpwood, export, demand share, transcendental logarithmic, policy

ANALISIS PERMINTAAN BUBUR KERTAS INDONESIA DENGAN MENGGUNAKAN MODEL TRANSCENDENTAL LOGARITHMICH: STUDI DI DUNLA DAN BEBERAPA PASAR ASIA. Ekspor bubur kertas Indonesia telab menunjukkan trend yang meningkat sejak era 1990an. Bersama Brazil, Canada, US A, dan Chili, Indonesia menjadi satu dari lima pengekspor bubur kertas terbesar di dunia. Bubur kertas Indonesia sebagian besar diekspor ke negara-negara Asia. Tulisan ini menganalisis permintaan ekspor bubur kertas Indonesia periode 1994-2014 menggunakan model Trancendental Logarithmic (TL) dengan estimasi Seemingly Unrelated Regression (SUR). Data ekspor dari lima negara pengekspor bubur kertas terbesar di empat pasar yang berbeda (Cina, Korea, Jepang, dan dunia) dianalisis. Hasil penelitian menunjukean: pertama, logaritmik, pendapatan dan second order logaritmik, pendapatan yang berpengaruh signifikan di pasar Cina dan Korea; kedua, secara umum elastisitas harga bubur kertas Indonesia elastis dan negatif (-2,308, -1,06, dan -2,04 di pasar Korea, Jepang, dan dunia). Ketiga, sebubungan dengan nilai elastisitas yang positif pada harga bubur kertas negara lain dan juga positif pada elastisitas pendapatan (masing-masing 1,002, 1,722, dan 0,625 di pasar Cina, Korea, dan dunia), maka bubur kertas Indonesia dapat dikategorikan sebagai barang substitusi dan barang normal. Terakbir, terkait dengan nilai elastisitas harga bubur kertas Indonesia yang negatif dan elastis, satu

*Corresponding author: gunawan@iuj.ac.jp 
kebijakan yang dapat diterapkan oleh pemerintah Indonesia adalah pemberian subsidi untuk mengurangi harga bubur kertas Indonesia sebesar 10\%. Subsidi dapat diimplementasikan dengan mengurangi pajak dan retribusi seperti Pajak Bumi dan Bangunan (PBB) dan retribusi daerah. Dengan melakukan bal ini maka akan memberikan manfaat lebih banyak di pasar Korea dibandingkan dengan pasar bubur kertas lainnya. Share permintaan di pasar Korea akan meningkat dari 0,28 menjadi 0,31 dengan nilai rate of return yang tinggi (>2). Pada pasar dunia, share permintaan bubur kertas Indonesia akan meningkat dari 0,08 menjadi 0,1 dengan nilai rate of return sebesar 1,89. Oleh sebab itu, studi ini menyarankan agar pemberian subsidi dapat dilakukan pada industri bubur kertas di Indonesia.

Kata kunci: Bubur kertas, ekspor, share permintaan, transcendental logarithmic, kebijakan

\section{INTRODUCTION}

Forestry sector, including forest industries, comprised around $2.5 \%$ of Indonesian GDP during the period of 2012 - 2014 (Badan Pusat Statistik, 2016). Even though this sector's contribution to GDP is small compared to other sectors, forestry sector altogether with agriculture and fishery sectors has contributed by providing job opportunities. In addition, forestry sector is also considered as a booster for economic growth in Indonesia since forestry sector has contributed to the development of isolated areas (Nurrochmat et al., 2012).

Due to abundance of forest resources, Indonesia has become a major forest product exporter country in the world, specifically of pulpwood. In 2013, Indonesian pulpwood contributed 1.8 billion USD in total value added - second only to plywood (Kemenhut, 2014). This forest product has shown a dramatically increasing trend since 1990s. Pulpwood production reached more than 6 million tons in 2013. More than half of the total production (3.8 million tons) was traded mainly to some Asian countries such as China, Korea and Japan.

A demand for wood will continue to increase (FAO, 2009). In addition to this, Indonesia has been considered as a country that positively responds to wood global demand by expanding its pulp production and timber plantation industries (Obidzinski \& Dermawan, 2012). Thus, it is important to analyse the demand structure of pulpwood for Indonesia. This paper investigates the demand function of Indonesian pulpwood on several markets, namely the Chinese, Korean, Japanese and the world markets. These three countries were chosen because approximately $81.5 \%$ of the total Indonesian pulpwood export (2.8 million tons) went to these countries in 2014. In addition, these Asian countries are the main partner countries for Indonesian forest products trade (Indonesia EU FLEGT Facility, 2016).

Three objectives are examined in this study. First, to learn the demand functions of Indonesian pulpwood on both selected Asian countries (China, Korea and Japan) and the world market. Next is to measure own-prices, cross-prices and incomes elasticity of the top five pulpwood exporter countries (Brazil, Canada, USA, Chile and Indonesia) including its effects on Indonesian pulpwood demand. The last is to examine the policy that can be applied to Indonesia's pulpwood industries.

Forest products demand function altogether with income and price elasticity have been researched by some scholars. There are various methods which can be used to analyse demand functions. They are different due to variables included in the models, data and econometric approaches that are applied. Turner and Buongiorno (2004) derived import demand for 10 (ten) forest product groups from generalized Cobb-Douglas production function and compared 5 (five) different methods both in static and dynamic models (Pooled OLS, First Differencing, Fixed effects, Random Effects, and the Arellano-Bond method). The explanatory variables consist of real import 
price and real GDP as proxy of income. The study used panel data from 64 countries from 1970 to 1987. The results found that the dynamic Arellano-Bond method gave the best result in measuring demand function.

Similarly the demand functions model was also studied by Simangunsong and Buongiorno in 2001. The data were gathered from 64 countries during the period of 1973-1997. In addition, five different econometric approaches namely Pooled OLS, Least Squares with Dummy Variables (LSDV), within-country and between-country regression, random effects and shrinkage estimation were compared, both statically and dynamically, to measure demand functions for nine groups of forest products. The result showed that the Least Squares with Dummy Variables (LSDV) was the most useful method to obtain demand functions. In addition, the study stated that static model could predict demand model better than dynamic model.

Demand for goods can also be measured based on international trade terms. Gravity model, for instance, is a model to analyse demand for export and import between two countries. This model suggests that distance is an important factor on determining the demand function. Distance variable is expected to have negative sign or relation on export and import demand. Tang, Song, Perez-Garcia, and Eastin (2015) used this model to measure Chinese wood pulp and recovered paper imports. Three econometric approaches namely Random effects, Fixed effects and Hausman-Taylor (HT) estimator were applied in the paper. Particularly for pulpwood, the study formulated the demand function which consists of GDP of both importer and exporter country as proxy of the economic development level, distance, exchange rate, pulpwood production per capita, dummy variables of APEC and WTO agreements. The study used data from 1995 to 2012. The finding suggested that HT estimator gave the best estimation and gravity model succeed in explaining the Chinese pulpwood and recovered paper import.

Another approach to measure demand structure is Transcendental Logarithmic (TL) model which was first introduced by Christensen, Jorgenson, and Lau (1975). Then, the model was developed by Swamy and Binswanger (1983). The study compared three demand functions namely Normalized Quadratic demand, Generalized Leontief demand and Transcendental Logarithmic demand (TL). The result suggested that compared to the other demand functions, TL is better in terms of symmetry and homogeneity restrictions. Wilson (1994) added TL model is more general than the Almost Ideal Demand System (AIDS) model. Moreover, this model has flexibility in function form and satisfies all restrictions of demand function: homogeneity, symmetry and adding-up constraint.

Even though there are various models that can be used to study demand functions, most studies show that the sign of own-price and income elasticity are consistent. Own-price is negatively correlated with pulpwood demand, while income is positively correlated with the quantity of pulpwood demanded. However, the magnitude of own-price and income elasticity could be different. Some scholars, for instance, Turner and Buongiorno (2004) and Chou and Buongiorno (1984) found that own-price was inelastic (-0.48 and -0.88 , respectively), whereas Detomasi (1969) found pulp/waste paper's own-price was elastic (-12.55). Different results were also obtained for income elasticity. Turner and Buongiorno (2004) found the income elasticity was elastic (2.7), while Kreinin (1973) found income was inelastic (0.75).

This paper is clearly different with the previous studies in terms of the methodology. Most of them use Ordinary Least Square (OLS), fixed effects, random effects and other econometric approaches both in static and dynamic terms. Whereas, this study uses Transcendental Logarithmic (TL) model with Seemingly Unrelated Regression (SUR) estimation with more focus on demand for Indonesian pulpwood in the Chinese, Korean, Japanese and the world markets. Other than that, this model is a static model. Therefore, 
the result is expected to be more precise than dynamic models, especially in estimating the demand function.

\section{MATERIAL AND METHOD}

\section{A. Materials}

This study uses secondary data from United Nation Commodity Trade Statistics Database (International Trade Statistics, 2015). The data consists of volume (in tons) and value (in US\$) of pulpwood exported from the top five producer countries namely Brazil, Canada, USA, Chile and Indonesia. The prices are approximated by dividing the total value of pulpwood export with the total volume of pulpwood exported. The data series used is on an annual basis from 1994 to 2014. In addition, the world and some Asian countries (China, Korea and Japan) are chosen as pulpwood markets. Pulpwood that is used in this study is classified in Harmonized System (HS) 4703 (4 digits) and is defined as chemical wood pulp, soda or sulphate and not dissolving grade.

\section{B. Methods}

Transcendental Logarithmic (TL) function was introduced by Christensen et al. (1975) and then followed by Swamy and Binswanger (1983) is applied to estimate Indonesian chemical pulpwood demand on the Chinese, Korean, Japanese and the world markets.In general, Transcendental Logarithmic (TL) model can be seen as below.

$S_{i}=\alpha_{i}+\beta_{i 1} \log (M)+\beta_{i 2}(\log (M))^{2}+\sum_{j=1}^{N} \gamma_{i j} \log \left(P_{j}\right)$

where:

$$
\begin{array}{rl}
S_{i}= & \text { share of an exporter country } \mathrm{i} \\
& \text { in a particular market, } \\
\log (M)= & \text { logarithm of real expenditure/ } \\
& \text { income, } \\
(\log (M))^{2}= & \text { second order logarithm of real } \\
& \text { expenditure/income, } \\
\log \left(P_{j}\right) \quad & \text { logarithmic price of exporter } \\
& \text { country } \mathrm{j}, \\
\mathrm{j} & 1,2, \ldots, \mathrm{N} \text { (the number of } \\
& \text { exporter countries), }
\end{array}
$$

$$
=1,2, \ldots, \mathrm{N}-1 \text {. }
$$

Since this study uses export data from 5 top chemical pulpwood exporter countries (Brazil, Canada, USA, Chile and Indonesia) in 4 different markets (the world, China, Korea and Japan) then the model was reconstructed as follows:

$S_{i m}=\alpha_{i m}+\beta_{\text {lim }} \log M_{m}+\beta_{2 i m}(\log (M))^{2}+\sum_{j=1}^{N} \Upsilon_{i j m} \log \left(P_{j m}\right)$

where:

$S_{\text {im }}=$ share of an exporter country $\mathrm{i}$ in a particular pulpwood country market $\mathrm{m}$,

$\mathrm{m}=1,2,3,4$ refers to Chinese, Korean, Japanese and the world markets,

$=$ Number of exporter countries $(\mathrm{N})$.

$=1,2,3,4,5$ refer to Brazil, Canada, USA, Chile and Indonesia respectively, $\mathrm{i}=1,2, \ldots, \mathrm{N}-1$.

This study imposes demand restrictions on the model as follows:

Homogeneous of degree $0 \quad \sum_{j} Y_{i j m}=0 \quad \forall i m$ Symmetry $\quad \Upsilon_{i j}=\Upsilon_{j i} \quad \forall i m$

Along with the model, in order to avoid singularity, one equation should be omitted from the system. In this study, there are five equations of exporters' share demand in each market. Thus, one of them should be deleted. The dropped equation should be the least share from the exporter countries. However, on the Japanese and the world markets, the least share of pulpwood exporter is Indonesia, as a consequence the deleted equation is the second least exporter.

\section{Analysis}

Four steps were carried out in order to answer the objectives of this study. Firstly, the cross-equation error correlation was tested. Followed by estimating Indonesia's demand function using SUR estimation. Next price (own-and cross-price) elasticity and income elasticity was calculated using Eq. 3 and Eq. 4. The last was analysing the policy that could be implemented by the Indonesian government based on the yielded results. The STATA program was used to measure the first two 
aforementioned steps. The last two steps were calculated by using Excel Program through formula from Eq. 3 to Eq. 10.

1. Testing for cross-equation error correlation

Transcendental Logarithmic (TL) demand function using SUR estimation which was used in this study consisted of identical variables in all system of equations (Eq. 2). For that reason, Breusch and Pagan's test (Breusch and Pagan, 1980) was applied on STATA program to examine the correlation matrix of errors across the equations.

This error correlation can be captured by examining the covariance value. The hypothesis can be seen as follows:

$\mathrm{H}_{0}: \sigma 12=\sigma 13=\ldots=\sigma 45=0$; where $\sigma 12=$ $\sigma 13=\ldots=\sigma 45$ are defined as covariance of errors across different equations,

$\mathrm{H}_{1}$ : at least one covariance is nonzero,

$\mathrm{H}_{0}$ : can be rejected if any of covariance is nonzero.

\section{Price and income elasticity}

This study used Swamy and Binswanger's model to measure price and income elasticity. Swamy and Binswanger (1983) formulated price and income elasticity as follows:

\section{Price Elasticity:}

$$
E_{i j}=\frac{\Upsilon_{i j}}{\hat{S}_{i}}+\hat{S}_{j}-\delta_{i j} \quad i \neq j
$$

where:

$Y_{i j}=$ coefficient of $\mathrm{P}_{\mathrm{ij}}$,

$\mathrm{i}=$ exporter country $i$,

$j=$ other exporter country $j$,

$\hat{\mathrm{S}}_{i}=$ mean value of demand share exporter country $i$,

$\hat{\mathrm{S}}_{j}=$ mean value of demand share exporter country $j$,

$\delta_{i j}=$ Kronecker delta, $\delta_{i j}=1$ if $\mathrm{i}=\mathrm{j}$, and $\delta_{i j}=0$ otherwise.

Income Elasticity:

$E_{i m}=\frac{\beta_{i 1+} 2 \beta i 2 \log (M)}{\hat{\mathrm{S}}_{i}}+1 \mathrm{i}<\mathrm{n}$ where:

$$
\begin{aligned}
\beta_{i 1}= & \text { coefficient of logarithmic real } \\
& \text { income exporter country } i \\
\beta_{i 2}= & \text { coefficient of second order } \\
& \text { logarithmic real income exporter } \\
& \text { country } i \\
= & \text { exporter country } i \\
= & \text { mean value of demand share } \\
& \text { country } i \\
\hat{\mathrm{S}}_{i} \quad & \text { logarithm of real expenditure/ } \\
& \text { income on pulpwood. }
\end{aligned}
$$

\section{III.RESULT AND DISCUSSION}

\section{A. Breusch-Pagan Test of Error Correlation}

Table 1 shows the result of Breusch-Pagan test for pulpwood demand from the top five exporter countries on the Chinese, Korean, Japanese and the world markets. The correlation of the residuals among demand shares are nonzero, thus this study rejects $\mathrm{H}_{\mathrm{o}}$ ( $\sigma \mathrm{s} 1 \mathrm{~s} 2=$ $\sigma \mathrm{s} 2 \mathrm{~s} 3=\ldots=\sigma \mathrm{s} 4 \mathrm{~s} 5=0$ ). It means there are correlations among the residuals.

Table 2 shows Chi-square $\left(\mathrm{Chi}^{2}\right)$ values and probability values of Breusch-Pagan test of independencies. All probability values are considered small for all markets: 0.0045 (Chinese market), 0.0000 (Korean market), 0.0613 (Japanese market) and 0.0006 (the world market). The results indicate that the equations in each market is jointly either positively or negatively significant at level 1\% for Chinese, Korean and the world markets, and significant at $10 \%$ for Japanese pulpwood market. This study, therefore, can be continued by regressing Transcendental Logarithmic (TL) demand model with Seemingly Unrelated Regression (SUR) estimation.

\section{B. Seemingly Unrelated Regression (SUR) Estimation}

Table 3 represents SUR estimation of pulpwood demand for the top 5 exporter pulpwood countries in four different markets. Based on the list at row 8 on the Chinese market there are four significant independent variables, namely: logarithmic income $\left(\beta_{\mathrm{i} 1}\right)$, second order 
Table 1. Correlation matrix of residuals for the top five exporter countries on four different markets

\begin{tabular}{|c|c|c|c|c|c|c|c|c|c|}
\hline \multicolumn{10}{|c|}{ Breusch-Pagan test of error correlation } \\
\hline \multicolumn{5}{|c|}{ Export to China } & \multicolumn{5}{|c|}{ Export to Korea } \\
\hline & $\sigma_{\mathrm{s} 1}$ & $\sigma_{\mathrm{s} 2}$ & $\sigma_{\mathrm{s} 4}$ & $\sigma_{\mathrm{s} 5}$ & & $\sigma_{\mathrm{s} 2}$ & $\sigma_{\mathrm{s} 3}$ & $\sigma_{\mathrm{s} 4}$ & $\sigma_{\mathrm{s} 5}$ \\
\hline$\sigma_{\mathrm{s} 1}$ & 1.0000 & & & & $\sigma_{\mathrm{s} 2}$ & 1.0000 & & & \\
\hline$\sigma_{\mathrm{s} 2}$ & 0.0522 & 1.0000 & & & $\sigma_{\mathrm{s} 3}$ & 0.4094 & 1.0000 & & \\
\hline$\sigma_{\mathrm{s} 4}^{\mathrm{s} 2}$ & -0.0879 & -0.0347 & 1.0000 & & $\sigma_{\mathrm{s} 4}^{\mathrm{si}}$ & -0.7509 & -0.4715 & 1.0000 & \\
\hline$\sigma_{\mathrm{s} 5}$ & -0.2916 & -0.7043 & -0.5506 & 1.0000 & $\sigma_{\mathrm{s} 5}$ & -0.2058 & -0.6598 & -0.0631 & 1.0000 \\
\hline \multicolumn{5}{|c|}{ Export to Japan } & \multicolumn{5}{|c|}{ Export to the world } \\
\hline & $\sigma_{\mathrm{s} 1}$ & $\sigma_{\mathrm{s} 2}$ & $\sigma_{\mathrm{s} 3}$ & $\sigma_{\mathrm{s} 5}$ & & $\sigma_{\mathrm{s} 1}$ & $\sigma_{\mathrm{s} 2}$ & $\sigma_{\mathrm{s} 3}$ & $\sigma_{\mathrm{s} 5}$ \\
\hline$\sigma_{\mathrm{s} 1}$ & 1.0000 & & & & $\sigma_{\mathrm{s} 1}$ & 1.0000 & & & \\
\hline$\sigma_{\mathrm{s} 2}^{\mathrm{s} 1}$ & -0.0811 & 1.0000 & & & $\sigma_{\mathrm{s} 2}^{\mathrm{si}}$ & -0.7932 & 1.0000 & & \\
\hline$\sigma_{\mathrm{s} 3}$ & -0.1924 & -0.5286 & 1.0000 & & $\sigma_{\mathrm{s} 3}$ & 0.1823 & -0.5776 & 1.0000 & \\
\hline$\sigma_{\mathrm{s} 5}^{\mathrm{s} 3}$ & 0.1559 & -0.3843 & 0.2789 & 1.0000 & $\sigma_{\mathrm{s} 5}^{\mathrm{s3}}$ & -0.0101 & 0.0219 & -0.3582 & 1.0000 \\
\hline
\end{tabular}

Table 2. Chi-square $\left(\mathrm{Chi}^{2}\right)$ value with 6 degree of freedom for all markets

\begin{tabular}{clccl}
\hline No. & Test of independence & Chi $^{2}(6)$ & Probability & \\
\hline 1. & Export to Chinese market & 18.814 & 0.0045 & There are correlation among errors \\
2. & Export to Korean market & 30.142 & 0.0000 & There are correlation among errors \\
3. & Export to Japanese market & 12.028 & 0.0613 & There are correlation among errors \\
4. & Export to the world & 23.622 & 0.0006 & There are correlation among errors \\
\hline
\end{tabular}

logarithmic income $\left(\beta_{\mathrm{i} 2}\right)$, Canadian pulpwood price (12) and Indonesian pulpwood own-price (15). Similar patterns are also shown in the Korean market (row 16). Logarithmic income ( $\beta$ i1), second order logarithmic income ( $\beta \mathrm{i} 2$ ) and Indonesian pulpwood own-price (15) significantly influence Indonesia's pulpwood demand too. Yet, another country's price is influenced by USA's pulpwood price (Y3) instead of Canadian pulpwood price (12). On row 32, the list point out that Indonesia's pulpwood own-price (15) and USA's pulpwood price (13) influence Indonesia's pulpwood demand significantly on the world market as well. Particularly, on the Japanese pulpwood market (row 24) there is no significant independent variable.

Looking at in more details about Indonesian share demand on the Chinese market (row 7), the total expenditure or income denoted by Log (M) has positive sign on the coefficient variable $\left(\beta_{\mathrm{i} 1}\right)$. It means that the rise of expenditure will also increase the demand share of Indonesian pulpwood. Second order logarithmic income $(\log (\mathrm{M}))^{2}$ on demand share of Indonesian pulpwood has negative sign on coefficient parameter $\beta_{i 2}$, which means that the increase of Indonesian pulpwood demand due to an increasing expenditure will hold diminishing pattern. Furthermore, the coefficient of Indonesia's own-price (15) to the Chinese market is positive and explains that an increase of Indonesian pulpwood price will escalate the pulpwood export to China. On the other hand, other country's pulpwood price (Canada's $\left(\Upsilon_{2}\right)$ price) will negatively affect the share of Indonesian pulpwood demand and it is shown by the negative sign of the Canadian pulpwood 
Table 3. Seemingly Unrelated Regression (SUR) estimation

\begin{tabular}{|c|c|c|c|c|c|c|c|c|c|c|}
\hline \multirow{2}{*}{ Equations } & \multirow{2}{*}{$\begin{array}{c}\text { Dependent } \\
\text { Variables }\end{array}$} & \multicolumn{8}{|c|}{ Independent Variables } & \multirow{2}{*}{ Remarks } \\
\hline & & $\alpha \mathrm{i}$ & $\beta \mathrm{i} 1$ & $\beta \mathrm{i} 2$ & Y1 & $\mathrm{Y2}$ & $\Upsilon 3$ & $\Upsilon 4$ & $Y 5$ & \\
\hline \multicolumn{11}{|l|}{ Chinese market } \\
\hline \multirow[t]{2}{*}{ 1. Brazil } & S1 & -2.796 & 0.216 & -0.004 & 0.024 & 0.084 & 0.062 & -0.117 & -0.053 & \\
\hline & & $(4.363)$ & $(0.409)$ & $(0.009)$ & $(0.081)$ & $(0.076)$ & $(0.047)$ & $(0.074)$ & $(0.077)$ & \\
\hline \multirow[t]{2}{*}{ 2. Canada } & S2 & 35.191 & -3.217 & 0.074 & 0.084 & -0.032 & -0.031 & 0.267 & -0.288 & \\
\hline & & $(5.904) * * *$ & $(0.553)^{* * * *}$ & $(0.012)^{* * * *}$ & $(0.076)$ & $(0.142)$ & $(0.066)$ & $(0.111)^{* *}$ & $(0.099)^{* * * *}$ & (3) USA \\
\hline \multirow[t]{2}{*}{ 4. Chile } & S4 & -2.614 & 0.246 & -0.006 & -0.117 & 0.267 & -0.004 & -0.155 & 0.009 & $\begin{array}{c}\text { share } \\
\text { omitted }\end{array}$ \\
\hline & & $(6.553)$ & $(0.614)$ & $(0.014)$ & $(0.074)$ & $(0.111)^{* *}$ & $(0.061)$ & $(0.124)$ & $(0.099)$ & \\
\hline 5. Indonesia & S5 & -35.891 & 3.426 & -0.081 & -0.053 & -0.288 & -0.021 & 0.009 & 0.3545851 & \\
\hline (8) & & $(8.580) * * *$ & $(0.804)^{* * * *}$ & $(0.018)^{* * * *}$ & $(0.077)$ & $(0.077)^{* * * *}$ & $(0.070)$ & $(0.099)$ & $(0.154)^{* *}$ & \\
\hline \multicolumn{11}{|l|}{ Korean market } \\
\hline \multirow[t]{2}{*}{ 2. Canada } & S2 & -65.700 & 6.690 & -0.169 & 0.098 & -0.288 & -0.103 & 0.266 & 0.027 & \\
\hline & & $(86.598)$ & $(8.452)$ & $(0.206)$ & $(0.087)$ & $(0.195)$ & $(0.126)$ & $(0.152)^{*}$ & $(0.096)$ & \\
\hline \multirow[t]{2}{*}{ 3. USA } & S3 & -167.879 & 16.575 & -0.408 & 0.116 & -0.103 & -0.442 & 0.031 & 0.398 & \\
\hline & & $(68.033)^{* *}$ & $(6.645)^{* *}$ & $(0.162)^{* *}$ & $(0.079)$ & $(0.126)$ & $(0.157)^{* * *}$ & $(0.142)$ & $(0.088)^{* * * *}$ & (1) Brazil \\
\hline \multirow[t]{2}{*}{ 4. Chile } & S4 & 19.684 & -2.089 & 0.055 & -0.177 & 0.266 & 0.031 & 0.008 & -0.128 & $\begin{array}{c}\text { share } \\
\text { omitted }\end{array}$ \\
\hline & & $(76.701)$ & (7.488) & $(0.182)$ & $(0.088)$ & $(0.152)^{*}$ & $(0.142)$ & $(0.194)$ & $(0.099)$ & \\
\hline 5. Indonesia & S5 & 168.950 & -16.615 & 0.409 & 0.038 & 0.027 & 0.398 & -0.128 & -0.335 & \\
\hline (16) & & $(64.118)^{* * * *}$ & $(6.254)^{* * *}$ & $(0.152)^{* * *}$ & $(0.075)$ & $(0.096)$ & $(0.088)^{* * *}$ & $(0.099)$ & $(0.095)^{* * *}$ & \\
\hline \multicolumn{11}{|l|}{ Japanese market } \\
\hline \multirow{2}{*}{ 1. Brazil } & S1 & -18.318 & 1.778 & -0.043 & 0.160 & -0.075 & 0.086 & -0.130 & -0.040 & \\
\hline & & $(12.374)$ & $(1.182)$ & $(0.028)$ & $(0.052)^{* * *}$ & $(0.045)^{*}$ & $(0.046)^{*}$ & $(0.051)^{* *}$ & $(0.030)$ & \\
\hline \multirow[t]{2}{*}{ 2. Canada } & S2 & -30.041 & 2.727 & -0.061 & -0.075 & 0.038 & 0.125 & -0.088 & 0.001 & \\
\hline & & $(49.555)$ & $(4.742)$ & $(0.113)$ & $(0.045)^{*}$ & $(0.185)$ & $(0.104)$ & $(0.114)$ & $(0.080)$ & (4) Chile \\
\hline \multirow[t]{2}{*}{ 3. USA } & S3 & 57.595 & -5.365 & 0.125 & 0.086 & 0.125 & -0.203 & 0.022 & -0.031 & $\begin{array}{c}\text { share } \\
\text { omitted }\end{array}$ \\
\hline & & $(28.663)^{* *}$ & $(2.742)^{* *}$ & $(0.065)^{*}$ & $(0.046)^{*}$ & $(0.104)$ & $(0.099)^{* *}$ & $(0.085)$ & $(0.052)$ & \\
\hline 5. Indonesia & S5 & 0.877 & 0.000 & -0.002 & -0.040 & 0.001 & -0.031 & 0.078 & -0.007 & \\
\hline (24) & & $(23.871)$ & $(2.285)$ & $(0.054)$ & $(0.030)$ & $(0.080)$ & $(0.052)$ & $(0.057)$ & $(0.048)$ & \\
\hline \multicolumn{11}{|l|}{ the world market } \\
\hline \multirow[t]{2}{*}{ 1. Brazil } & S1 & 16.056 & -1.514 & 0.036 & -0.145 & 0.146 & 0.109 & -0.122 & 0.012 & \\
\hline & & $(30.820)$ & $(2.650)$ & $(0.056)$ & $(0.037)^{* * *}$ & $(0.052)^{* * *}$ & $(0.031)^{* * *}$ & $(0.038)^{* * *}$ & $(0.021)$ & \\
\hline \multirow[t]{2}{*}{ 2. Canada } & S2 & -51.676 & 4.740 & -0.107 & 0.146 & -0.153 & -0.203 & 0.187 & 0.022 & \\
\hline & & (48.711) & $(4.189)$ & $(0.090)$ & $(0.052)^{* * *}$ & $(0.103)$ & $(0.057)^{* * * *}$ & $(0.060)^{* * *}$ & $(0.033)$ & (4) Chile \\
\hline \multirow[t]{2}{*}{ 3. USA } & S3 & 5.236 & -0.464 & 0.011 & 0.109 & -0.203 & 0.074 & -0.045 & 0.065 & $\begin{array}{c}\text { share } \\
\text { omitted }\end{array}$ \\
\hline & & $(39.655)$ & $(3.410)$ & $(0.073)$ & $(0.031)^{* * *}$ & $(0.057)^{* * *}$ & $(0.050)$ & $(0.044)$ & $(0.025)^{* *}$ & \\
\hline 5. Indonesia & S5 & 33.665 & -2.919 & 0.063 & 0.012 & 0.022 & 0.065 & -0.023 & -0.075 & \\
\hline (32) & & $(23.497)$ & $(2.019)$ & $(0.043)$ & $(0.021)$ & $(0.033)$ & $(0.025)^{* *}$ & $(0.032)$ & $(0.022)^{* * * *}$ & \\
\hline
\end{tabular}

Note: The numbers in parentheses are standard errors, $\left({ }^{* *}\right)$ significant at $1 \%,\left({ }^{* *}\right)$ significant at $5 \%,\left({ }^{*}\right)$ significant at $10 \%$

price. It suggests that an increase of Canadian pulpwood price will decrease the demand share of Indonesian pulpwood.

On contrary, the opposite result is obtained for demand of Indonesian pulpwood on the Korean market (row 15). Pulpwood demand in this country has negative sign of coefficient parameter $\beta_{\mathrm{i} 1}$ in respond to income variable $(\log (\mathrm{M}))$. An increase of expenditure will decrease the demand share of Indonesia's pulpwood export. Furthermore, the second order logarithmic expenditure $(\log (\mathrm{M}))^{2}$ shows positive sign instead of negative sign of coefficient parameter $\beta_{\mathrm{i} 2}$.

In relation to Indonesia's own-price (15), the coefficient of this variable is negative on the Korean market. It means that an increase of its own-price will decrease the demand share of Indonesian pulpwood export to Korea. Meanwhile, share of Indonesian pulpwood demand is positively influenced by USA's pulpwood price (13). The increase of USA's pulpwood prices will positively correspond to an increase of Indonesian pulpwood export.

Similar results related to the sign of its ownprice and other country variables are shown in the world market on row 31. The coefficient of Indonesia's own-price (15) is negative which means that an increase of its own-price will decrease the demand share of Indonesian 
Table 4. Own- and cross-price elasticity of pulpwood demand

\begin{tabular}{|c|c|c|c|c|c|}
\hline \multirow{2}{*}{$\begin{array}{c}\text { No. } \\
1 . \\
\end{array}$} & \multirow{2}{*}{$\begin{array}{l}\text { Markets } \\
\text { China }\end{array}$} & \multicolumn{3}{|c|}{ Cross-Price Elasticity } & \multirow{2}{*}{$\begin{array}{c}\text { Own-price } \\
\text { Elasticity } \\
\text { Indonesia }\end{array}$} \\
\hline & & Brazil & Canada & Chile & \\
\hline & Brazil & -0.687 & 0.902 & -0.640 & -0.144 \\
\hline & Canada & 0.409 & -0.783 & 1.011 & -0.680 \\
\hline & Chile & -0.543 & 1.893 & -1.746 & 0.277 \\
\hline & Indonesia & -0.091 & $-0.951(* * *)$ & 0.207 & 0.789 \\
\hline \multirow[t]{5}{*}{2.} & Korea & Canada & USA & Chile & Indonesia \\
\hline & Canada & -1.659 & -0.118 & 1.048 & 0.310 \\
\hline & USA & -0.158 & -2.743 & 0.301 & 1.990 \\
\hline & Chile & 1.929 & 0.416 & -0.789 & -0.565 \\
\hline & Indonesia & 0.423 & $2.038(* * *)$ & -0.419 & -2.308 \\
\hline \multirow[t]{5}{*}{3.} & Japan & Brazil & Canada & USA & Indonesia \\
\hline & Brazil & 0.347 & -0.128 & 0.954 & -0.246 \\
\hline & Canada & -0.038 & -0.471 & 0.583 & 0.063 \\
\hline & USA & 0.417 & 0.858 & -1.372 & -0.040 \\
\hline & Indonesia & -0.530 & 0.454 & -0.197 & -1.060 \\
\hline \multirow[t]{5}{*}{4.} & the world & Brazil & Canada & USA & Indonesia \\
\hline & Brazil & -1.656 & 1.234 & 0.867 & 0.134 \\
\hline & Canada & 0.543 & -0.988 & -0.267 & 0.124 \\
\hline & USA & 0.621 & -0.433 & -0.452 & 0.332 \\
\hline & Indonesia & 0.347 & 0.729 & $1.194(* *)$ & -2.048 \\
\hline
\end{tabular}

pulpwood export to the world market. The share of Indonesian pulpwood export is also positively affected by USA's pulpwood price $\left(\Upsilon_{3}\right)$. Then, the increase of USA's pulpwood prices will correspond to an increase of Indonesian pulpwood export to the world market.

\section{Price and Income Elasticity}

1. Own- and cross-price elasticity

Table 4 shows the own- and cross-price elasticity of pulpwood demand for the top five exporter countries. Own-price elasticity indicates that the change in pulpwood demand correspond to the change in the price of the same goods. Looking in more detail, the ownprices show negative signs for Indonesian pulpwood on the Korean, Japanese and the world markets. The value of own-price elasticity is $-2.308,-1.06$ and -2.04 on the Korean, Japanese and the world markets respectively, which are considered as elastic. It means that an increase in Indonesian pulpwood price will bring a significant negative effect on pulpwood demand by those markets. This is supported by Detomasi (1969) which resulted in -12.55 of own-price, while Turner and Buongiorno (2004) suggested that own-price of pulpwood is considered as inelastic and accounted for -0.84 of own-price elasticity. Thus, this study conform the demand theory that the higher the price of pulpwood the smaller quantity will be demanded. It has happened on the Korean, Japanese and the world market.

Interestingly, different result is shown for demand of Indonesian pulpwood on the Chinese market. The own-price is inelastic $(<1)$, and it has a positive sign which means that Indonesian pulpwood price will not give a significant effect on the Chinese pulpwood demand. In addition, if the price of Indonesian pulpwood goes up, the demand of Indonesian pulpwood will keep increasing. One of the possible explanations of why China keeps continuing to import Indonesian pulpwood even though the price rise is due to its high economic growth (Tang et al., 2015). Another explanation is that Indonesian pulpwood production keeps growing and able to meet 
Table 5. Income elasticity of pulpwood demand among top five pulpwood exporter countries

\begin{tabular}{cccc}
\hline No. & Markets & Exporter countries & Income elasticity \\
\hline 1. & China & & \\
\hline & & Brazil & 1.413 \\
& Canada & 0.733 \\
& & Chile & 1.072 \\
& & Indonesia & $\mathbf{1 . 0 0 2}$ \\
\hline 2. & Korea & Canada & 0.169 \\
& & USA & 0.226 \\
& & Chile & 2.085 \\
& & Indonesia & $\mathbf{1 . 7 2 2}$ \\
\hline 3. & Japan & Brazil & 1.033 \\
& & Canada & 1.481 \\
& & USA & 0.460 \\
& & Indonesia & $\mathbf{- 0 . 3 0 8}$ \\
\hline 4. & Global world & Brazil & 1.655 \\
& & Canada & 0.581 \\
& & USA & 1.119 \\
& & Indonesia & $\mathbf{0 . 6 2 2}$ \\
\hline
\end{tabular}

China's demand.

The cross-price elasticity in four markets varies within the top five pulpwood exporter countries. Positive cross-price elasticity indicates that pulpwood is substitute goods, while the negative elasticity shows that the pulpwood is complementary goods. The results show that both substitute and complementary goods exist in pulpwood trade in all markets. However, according to the result, pulpwood can be considered as a substitute goods. This is clearly shown in Table 5 that out of three significant cross-prices elasticity, two (2) of them (USA's pulpwood prices) have positive sign (2.038 and 1.194 on the Korean and the world markets, respectively). It means that Indonesian pulpwood product can be substituted by USA's pulpwood products.

\section{Income elasticity}

Table 5 represents income elasticity of pulpwood demand from the top five exporter countries. Changes of world income induce a positive influence on the share demand of Indonesian pulpwood to the Chinese, Korean and the world markets. Income elasticity is elastic in the Chinese and Korean markets (1.002 and 1.722, respectively). These results are supported by Turner and Buongiorno's study in 2004 which mentioned that income is elastic for pulpwood product (2.72). Meanwhile, income is considered as an inelastic elasticity in the world market (0.625).

As the economic theory mention, a positive sign of income elasticity indicates normal goods, while the negative elasticity is categorized as inferior goods. Based on the results above, Indonesian pulpwood can be considered as normal goods. This is shown in Table 5 that out of four income elasticity values, three (3) of them have positive signs. It means that the higher the expenditure on pulpwood, the more Indonesian pulpwood is demanded. However, particularly on the Japanese market, income has negative effect on demand of Indonesian pulpwood export.

An elastic income on demand of Indonesian pulpwood brings advantage for Indonesian pulpwood exporters to the Chinese and Korean markets. For instance, if Chinese and Korean 
consumers have higher income in the future, both countries will spend larger portion of their income for Indonesian pulpwood. On the other hand, if their incomes decrease, these two countries will import the pulpwood from Canada. Then, Indonesian pulpwood demand will decrease.

\section{Policy Analysis}

This study finds that Indonesia's pulpwood own-prices are mostly negative and elastic. This negative and elastic own-price indicates that a slightly reduced Indonesian pulpwood price would bring a huge increase in quantity demand of Indonesian pulpwood. Thus, one possible policy that could be implemented by the Government of Indonesia (GoI) is imposing a subsidy policy. The author conducted a scenario in which the GoI gives subsidy to pulpwood companies in order to reduce pulpwood price by $10 \%$. Similar policy had been implemented by the GoI when the GoI imposed a plantation subsidy to HTI holders from the Reforestation Fund (Dana Reboisasi) between 1993 and 1998 (Barr, 2001). A -10\% subsidy scenario is chosen since it would give a higher rate of return compared to a $-20 \%$ subsidy.

Generally, forest industry including pulpwood industry has linkage or connection with the forest plantation industry which is called forward linkage (Nurrochmat et al., 2016). Giving subsidy to forest plantation industry would give benefit for the pulpwood industry as well, for instance the lower raw material (wood) cost for pulpwood industry. Thus, it would finally cause in lower price of pulpwood produced. In addition, Nurrochmat et al. (2016) mentioned that giving subsidy to local producers is one of several ways to promote forest products export. In this paper, giving subsidy could be implemented by reducing tax and retribution such as property tax (Pajak Bumi dan Bangunan) and local retribution (Retribusi Daerab) that still are considered high.

Suppose the current Indonesian pulpwood sales $(\mathrm{M})$ is price $(\mathrm{P}) \mathrm{x}$ quantity $(\mathrm{Q})$. By doing so, it will lead to the decrease of the initial price
(P) to the new pulpwood price $\left(\mathrm{P}^{\prime}\right)$. At the new price, $10 \%$ cheaper than the Indonesian pulpwood price in 2014, the quantity of Indonesian pulpwood demand is expected to increase in all markets. The increase in quantity $(\Delta \mathrm{Q})$ can be calculated by using the formula:

$$
\Delta Q(\text { intons })=10 \% \times \varepsilon \times Q
$$

Then, the total Indonesian pulpwood demand becomes:

$$
Q^{\prime}=\Delta Q+Q
$$

Thus, the total new sales $\left(\mathrm{M}^{\prime}\right)$ can be measured as follow:

$$
M^{\prime}=P^{\prime} \times Q^{\prime}
$$

In regard to examine whether giving subsidy of $10 \%$ gives benefit for Indonesia or not, thus the gain yielded, cost needed, and the rate of return resulted due to this policy should be compared. Suppose world sales do not change, the total sales (M) of Indonesian pulpwood would increase by $\boldsymbol{\varepsilon}$. The gain yielded due to the policy can be calculated by the gain equation below:

$$
\text { Gain }=10 \% \times \varepsilon \times M
$$

Then, the cost that the GoI should spend can be estimated by using formula:

Cost $=10 \% \times Q^{\prime} \times P^{\prime}$

Therefore, rate of return of this policy can be measured by the formula below:

Rate of Return $=\frac{\text { Gain }}{\text { Cost }}$

Table 6 shows the projection of this scenario. Based on the assumption, the quantity of Indonesian pulpwood demand would increase in the Korean, Japanese and the world markets. In line with these increments, Indonesia's share of demand would also increase from 0.28 to 0.31 and from 0.08 to 0.1 in the Korean and the world markets, respectively. In contrast on the Japanese market, the share of pulpwood demand from Indonesia would eventually decrease from 0.09 to 0.08 . While in the Chinese 
Table 6. Subsidy scenario: GoI gives subsidy that reduces Indonesian pulpwood price by $10 \%$

\begin{tabular}{|c|c|c|c|c|}
\hline No. & Markets & Items & Initial values & $\begin{array}{l}\text { Projection of subsidy } \\
\text { scenario }\end{array}$ \\
\hline \multirow[t]{6}{*}{1.} & China & Total sales (USD) & $1,087,434,050$ & $901,513,402$ \\
\hline & & Quantity (tons) & $2,202,894$ & $2,029,179$ \\
\hline & & GoI's cost (USD) & - & $90,151,340$ \\
\hline & & Gain (USD) & - & $85,752,492$ \\
\hline & & Rate of return & - & 0.95 \\
\hline & & Share of demand & 0.17 & 0.14 \\
\hline \multirow[t]{6}{*}{2.} & Korea & Total sales (USD) & $238,704,096$ & $264,411,639$ \\
\hline & & Quantity (tons) & 493,626 & 607,542 \\
\hline & & GoI's cost (USD) & - & $26,441,164$ \\
\hline & & Gain (USD) & - & $55,086,614$ \\
\hline & & Rate of return & - & 2.08 \\
\hline & & Share of demand & 0.28 & 0.31 \\
\hline \multirow[t]{6}{*}{3.} & Japan & Total sales (USD) & $76,857,082$ & $76,502,115$ \\
\hline & & Quantity (tons) & 154,582 & 170,965 \\
\hline & & GoI's cost (USD) & - & $7,650,211$ \\
\hline & & Gain (USD) & - & $8,145,268$ \\
\hline & & Rate of return & - & 1.06 \\
\hline & & Share of demand & 0.09 & 0.08 \\
\hline \multirow[t]{6}{*}{4.} & World & Total sales (USD) & $1,718,324,937$ & $1,863,230,100$ \\
\hline & & Quantity (tons) & $3,497,111$ & $4,213,356$ \\
\hline & & GoI's cost (USD) & - & $186,323,010$ \\
\hline & & Gain (USD) & - & $351,930,730$ \\
\hline & & Rate of return & - & 1.89 \\
\hline & & Share of demand & 0.08 & 0.10 \\
\hline
\end{tabular}

market, the pulpwood quantity demand would decrease. Furthermore, the share of Indonesian pulpwood demand would also be decreasing from 0.17 to 0.14 .

In terms of implementing the subsidy policy, GoI would spend 90.15 million USD, 26.44 million USD, 7.65 million USD, and 186.32 million USD in the Chinese, Korean, Japanese, and the world markets, respectively. Indonesian pulpwood industry will gain 85.75 million USD with the rate of return of 0.95 in the Chinese market, 55.08 million USD with the rate of return of 2.08 in the Korean's market, 8.14 million USD with the rate of return of 1.06 in the Japanese market, and 351.93 million USD with the rate of return of 1.89 in the world market. It means that giving a subsidy would give more benefit to the Indonesian pulpwood industry in the Korean's market rather than on the other markets. Regarding the market share,
Indonesia's share of demand would increase from 0.08 to 0.1 in the world market. This study, therefore, suggests that a subsidy policy should be implemented on the Indonesian pulpwood industry.

Studying the demand function by using Transcendental Logarithmic (TL) model indeed gives flexibility in function form and satisfies all restrictions of demand function. This model, however, still has limitations. Since it is a static model, thus it cannot be used to forecast a demand function in a particular time because the forecast result would be the same for each year. In addition, it cannot give trends of Indonesian pulpwood export demand during the study period. Thus, policy makers still need to consider the dynamic model in order to capture the trends and to construct various projections. 


\section{CONCLUSION}

This paper finds that the demand of Indonesian pulpwood is significantly influenced by both logarithmic income (Log (M)) and second order logarithmic income $(\log (\mathrm{M}))^{2}$ in the Chinese and Korean markets. Canada's pulpwood price (\2) significantly affects Indonesian pulpwood demand in the Chinese market, while USA's pulpwood price (Y3) affects Indonesian pulpwood demand in the Koreans and the world markets. Indonesia's own-price (15) significantly influences its own demand in all markets, except for the Japanese market.

Regarding to elasticity, this paper highlights Indonesia's own-prices in almost all of the markets are elastic and have negative signs $(-2.308,-1.06$ and -2.04 in the Korean, Japanese and the world markets, respectively), whereas, Indonesia's own-price is inelastic and has positive sign only in the Chinese market (0.789). There are two possible explanations for this situation. Firstly, China keeps continuing the high economic growth. Another explanation is that Indonesian pulpwood production could meet China's demand.

Concerning the cross-price elasticity, this study finds that out of 3 (three) significant cross-prices elasticity, two (2) of them (USA's pulpwood prices) have positive sign (2.038 and 1.194 in the Korean and the world markets, respectively). The positive sign of cross-price elasticity explains that Indonesian pulpwood product can be substituted by USA's pulpwood.

In term of income elasticity, Indonesian pulpwood can be categorized as normal goods due to its positive sign in majority markets (1.002, 1.722 and 0.625 in the Chinese, Korean and the world markets, respectively). It means that increase of income leads to increase of pulpwood demand. On contrary, income elasticity has negative sign in the Japanese market with the value less than one (-0.308). It means that income is not a significant factor for the Japanese pulpwood demand.

Based on the policy analysis projection, the scenario assumes that GoI imposes subsidy in order to reduce Indonesia's pulpwood price by $10 \%$. This study points out that this scenario would give more benefit in the Korean market compared with other markets. It has high rate of return $(>2)$. Overall, in terms of market share, Indonesia's share of demand would increase from 0.08 to 0.1 with rate of return 1.89 in the world market. This study, therefore, suggests that a subsidy policy should be implemented for pulpwood industry in Indonesia.

\section{ACKNOWLEDGEMENT}

The authors would like to thank the National Development Planning Agency (BAPPENAS) and the Ministry of Environment and Forestry Republic of Indonesia for the funding to carry out this research. The authors also thank all reviewers for their contributions.

\section{REFERENCES}

Badan Pusat Statistik. (2016). percentage distribution of gross domestic product at current market prices by industrial origin, 2000-2014. Retrieved from http://www.bps.go.id/linkTabelStatis/ view/id/1207 on 3 January 2016.

Barr, C. (2001). Banking on sustainability ( $1^{\text {st }} \mathrm{ed}$.). Washington, DC: WWF Macroeconomics Program Office.

Breusch, T. S., \& Pagan, A. R. (1980). The lagrange multiplier test and its applications to model specification in econometrics. The Review of Economic Studies, 47(1), 239-253. doi:10.2307/2297111

Chou, J. J., \& Buongiorno, J. (1984). Demand functions for United States forest product exports to the European economic community. Wood and Fiber Science, 16(2), 158-168.

Christensen, L. R., Jorgenson, D. W., \& Lau, L. J. (1975). Transcendental logarithmic utility functions. The American Economic Review, 65(3), 367-383.

Detomasi, D. D. (1969). The elasticity of demand for Canadian exports to the United States. The Canadian Journal of Economics, 2(3), 416426. 
EU FLEGT Facility. (2016). Euflegt.efi.int. Retrieved from http://www.euflegt.efi.int/ indonesia on 1 November 2016.

FAO. (2009). State of the world's forests 2009 (1 $1^{\text {st }} \mathrm{ed}$.). Rome: FAO.

International Trade Statistics. (2015). Comtrade. un.org. Retrieved from https://comtrade. un.org/data/ on 7 November 2015.

Kementerian Kehutanan. (2014). Statistik kebutanan Indonesia tabun 2013. Jakarta: Biro Perencanaan, Kementerian Kehutanan.

Kreinin,M.E.(1973). Disaggregated import demand functions : Further results. Southern Economic Journal, 40(1), 19-25.

Nurrochmat, D. R., Hasan, M. F., Suharjito, D., Budiaman, A., Hadianto, A., Ekayani, M., Ryandi, E.D. (2012). In: D.R. Nurrochmat \& M.F. Hasan (Eds.). Ekonomi politik kehutanan. Mengurai mitos dan fakta pengelolaan butan. ( $2^{\text {nd }}$ edition, revised version). INDEF: Jakarta.

Nurrochmat, D.R., Darusman, D.R., Ekayani, M. (2016). Kebijakan pembangunan kebutanan dan lingkungan: Teori dan implementasi. Bogor: IPB Press.

Obidzinski, K. \& Dermawan, A. (2012). Pulp industry and environment in Indonesia: is there sustainable future?. Regional Environmental Change, 12(4), 961-966. doi:10.1007/s10113-012-0353-y.
Simangunsong, B. \& Buongiorno, J. (2001). International demand equations for forest products: A comparison of methods. Scandinavian Journal of Forest Research, 16(2), 155-172. doi:10.1080/028275801300088242.

Swamy, G. \& Binswanger, H. (1983). Flexible consumer demand systems and linear estimation: Food in India. American Journal of Agricultural Economics, 65(4), 675-684. doi:10.2307/1240455.

Tang, S., Song, W., Perez-Garcia, J., \& Eastin, I. L. (2015). An empirical analysis of China's wood pulp and recovered paper imports using an augmented gravity model approach. Forest Products Journal, 65(7-8), 381-386. doi:10.13073/fpj-d-14-00080.

Turner, J. A., \& Buongiorno, J. (2004). Estimating price and income elasticities of demand for imports of forest products from panel data. Scandinavian Journal of Forest Research, 19(4), 358-373. doi:10.1080/02827580410030127.

Wilson, W. W. (1994). Demand for wheat classes by Pacific Rim countries. Journal of Agricultural and Resource Economics, 19(1), 197-209. 